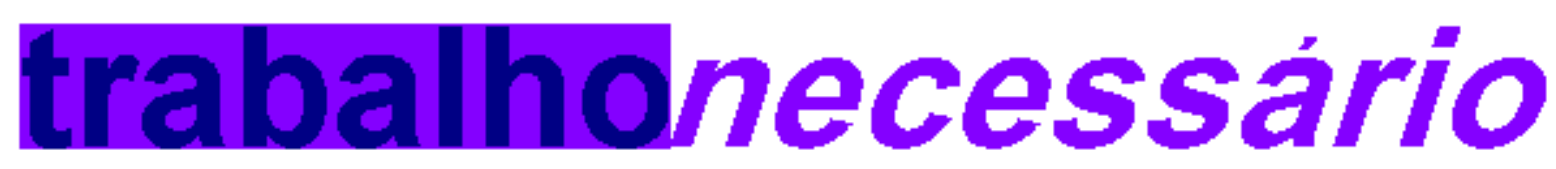

issn: $1808-799 X$

ano 5 - número 5 - 2007

artigo

\title{
A democratização do ensino com Anísio Teixeira versus educação brasileira em tempos de neoliberalismo[*]
}

Edison Riuitiro Oyama[**]

\section{INTRODUÇÃO}

Nosso objetivo com o presente artigo foi investigar o tema democratização do ensino na sociedade brasileira no contexto do modo de produção capitalista. Assim, com base numa concepção ampla de democracia (econômica, política, social, educacional) e numa caracterização geral do capitalismo, partimos da hipótese de trabalho de que é impossível alcançar-se o exercício democrático em seu sentido pleno, em virtude das limitações estruturais impostas às diversas dimensões do real pela lógica do modo de produção vigente. Nesse sentido, mesmo os avanços eventualmente obtidos no terreno da democracia tendem a perder-se, retroagir e por vezes tornarem-se reacionários, por conta das características essenciais do sistema capitalista. 
A democratização do ensino com Anísio Teixeira versus educação brasileira em te... Página 2 de 32

Dessa forma, no tocante à educação escolar, propusemo-nos a comparar dois acontecimentos inscritos temporalmente em momentos distintos: a) a questão da democratização do ensino com Anísio Teixeira quando da sua atuação como Secretário da Educação e Cultura do Distrito Federal nos anos de 1931-1935; b) contrapor o resultado dessa investigação, numa reflexão de como os ganhos obtidos por Anísio Teixeira na área educacional em parte se perderam ou foram voluntariamente desvirtuados, mediante os influxos e as necessidades do modo de regulação[1] contemporâneo.

Assim, além da Introdução e das Considerações Finais, no item 1 tratamos do tema democratização do ensino com Anísio Teixeira, com ênfase na análise de dados estatísticos sobre os resultados obtidos em sua gestão como Secretário da Educação do Distrito Federal nos anos de 1931 a 1935. Nos itens 2 e 3 expusemos respectivamente as características principais do capitalismo contemporâneo e a inserção do Brasil no mesmo. Finalmente, no item 4 fizemos o cotejo das informações apresentadas no item 1, com base em aspectos da realidade social e educacional do Brasil.

\section{A democratização do ensino com Anísio Teixeira}

A escolha do assunto democratização do ensino com Anísio Teixeira quando da sua atuação como Secretário da Educação no Distrito Federal, nos anos de 1931-1935 não foi fortuita. Primeiramente, é lícito afirmar que a defesa da democracia e da educação para a democracia constituem o motivo central do devotamento de sua vida. Defesa que não foi apenas apaixonada, mas polida por uma filosofia da educação e uma compreensão aguda da sociedade (NUNES, 2002, p.73; NUNES, 2004). Some-se a isso o fato de que Anísio Teixeira detinha uma erudição filosófica invejável; um conhecimento profundo sobre a realidade e a educação brasileiras; era um administrador hábil e competente, provavelmente com grande capacidade de liderança, que conseguia agregar em torno de si pessoas de diferentes personalidades, posturas político-partidárias e pontos de vista distintos, conciliando como poucos o saber com o agir. Ou seja, com base no conhecimento e na leitura da realidade, buscava transformar o mundo através da ação, personificando um desses homens que se dispunham efetivamente a intervir no real.

Foi também um opositor feroz da sociedade e da educação oligárquica e patriarcal existente até o início dos anos 1930:

Era contra a educação como processo exclusivo de formação de uma elite; o analfabetismo; a ausência, a evasão e a repetência da criança na escola; a falta de consciência pública para situação tão grave; a desvinculação do ensino médio das exigências da sociedade moderna; a seletividade extrema no ingresso às universidades; o esvaziamento do ensino superior e a dispersão de esforços pela multiplicidade, nesse nível de ensino, de escolas improvisadas em vez da expansão e fortalecimento das boas escolas. (NUNES, 2002, p.78) 
A democratização do ensino com Anísio Teixeira versus educação brasileira em te... Página 3 de 32

Fundamentado solidamente numa teoria sobre o Estado, Anísio Teixeira defendia a concepção de que a educação é um bem público e portanto, deveria ser subvencionada pelo erário. Nesse sentido, a educação não é um privilégio, mas um direito universal de todos. Para ele a forma democrática da sociedade tem como base a educabilidade humana, a qual é concebida como um processo deliberado, sistemático, progressivo e sempre inacabado de formação do indivíduo. Por esse raciocínio, educação e Estado estabelecem relações intrínsecas em que a primeira é condição sine qua non para a existência do segundo (TEIXEIRA, 2004, p.97).

Atuou na esfera pública em vários momentos de sua vida, dos quais destacamos: nos anos de 1924-1929, como Inspetor Geral do Ensino da Bahia; de 1931 a 1935, como Secretário da Educação e Cultura do Distrito Federal; em 1946-1950, como Secretário de Educação e Saúde do Estado da Bahia; foi ainda um dos idealizadores da Universidade de Brasília fundada em 1961, da qual tornou-se reitor em 1963, sendo depois destituído do cargo em 1964 (NUNES, 2002).

Eleger o período de 1931 a 1935, quando da atuação de Anísio Teixeira como Secretário da Educação e Cultura do então Distrito Federal deu-se pela importância que tal cargo assumia no contexto da educação escolar no Brasil. Nessa condição Anísio Teixeira projetou-se nacionalmente, ao implementar uma série de ações que serviriam de modelo aos sistemas educacionais em território nacional. Em sua gestão promoveu reformas nas áreas de financiamento da educação, formação de professores e currículo. Construiu prédios escolares, modificando instalações e equipando-os (TEIXEIRA, 1997). Pôde colocar em prática os princípios da proeminência da escola municipal no conjunto do sistema escolar; da prioridade atribuída ao ensino primário; e da relação de continuidade e mútua dependência entre o ensino primário, médio e superior.

Conforme segue abaixo, nossa pesquisa baseou-se exclusivamente no Capítulo VIII - A expansão escolar - do livro Educação pública (TEIXEIRA, 1935), o qual constitui relatório da atuação de Anísio Teixeira como Secretário da Educação do Distrito Federal durante o período estudado por nós. Sendo assim, foram examinadas informações estatísticas fornecidas pelo próprio autor, no que tange à relação entre número de matrículas/população infantil em idade escolar; aumento do número de matrículas; comparação entre séries históricas dos anos de 1910-1919, 1920-1929 e 1930-1934, sobre o aumento do número de matrículas; atendimento da população em idade escolar. Foi estudada também a questão da eficiência/eficácia do sistema, por meio do exame dos índices de aprovação dos alunos.

Segundo Teixeira (1935), em 1927, no Distrito Federal, a população infantil total era de 114.394 crianças, sendo que 66.804 estavam matriculadas nas escolas elementares diurnas, ou 58,39\% da população em idade escolar. Já em 1934 (quase ao 
A democratização do ensino com Anísio Teixeira versus educação brasileira em te... Página 4 de 32

final da sua gestão) havia uma população infantil de 142.392 crianças, sendo que 110.068 eram alunos matriculados nas escolas elementares diurnas, ou $77,29 \%$ da população em idade escolar. Ou seja, houve um crescimento no valor percentual de 18,9\% nas matrículas da população em idade escolar.

Com relação ao aumento anual do número de matrículas (consultar Tabela 1[2]), é interessante notar que a partir de 1931 (início da gestão de Anísio Teixeira) ocorreram oscilações ano a ano para mais ou para menos no aumento do número de matrículas, mas que no seu conjunto houve um aumento progressivo, sendo que de 1932 a 1934, o acréscimo foi de $22,17 \%$ sobre 1931, com destaque para o ano de 1934, cujo valor percentual foi de $14,70 \%$, este bastante superior aos valores dos anos anteriores.

Analisando-se as séries históricas expressas nas Tabelas 2 a 4, no que se refere ao número de matrículas nas escolas primárias diurnas e noturnas e jardim de infância, para os anos de 1910 a 1934, com base na Tabela 4, constatamos que houve um acréscimo consistente para os anos de 1930 a 1934 (com exceção do ano de 1932), em comparação aos dados das Tabelas 2 e 3, nas quais a variação do aumento foi bastante grande. Note-se que nos anos de 1923 a 1926 houve refluxo no número de matrículas, cujo pico negativo ocorreu em 1924 (seria uma possível influência externa da Primeira Guerra Mundial e da recessão mundial do sistema capitalista?). Também o valor médio absoluto da Tabela 4 - aumento médio de 7.188,5 matrículas - é significativamente superior ao das Tabelas 2 e 3. No que se refere ao valor médio percentual - 7,59\% - este é ligeiramente inferior à media relativa da Tabela 2 - 7,62\% - (cuja compensação se dá pelo fato de que o tempo calculado para a Tabela 4 é menor do que aquele para a Tabela 2), mas bastante superior à média da Tabela 3, que foi de $0,37 \%$.

Ainda com relação ao tema democratização do ensino, outra variável interessante de ser analisada é o número de crianças em idade escolar atendidas no sistema público elementar. Nesse sentido, com base nas Tabelas 5 a 10 inferimos que houve aumento progressivo referente ao ingresso do número de estudantes, considerando-se as séries do ensino elementar durante a gestão de Anísio Teixeira à frente da Secretaria de Educação, com destaque para a primeira série (Tabela $5-7$ anos), terceira série (Tabela $7-9$ anos) e quarta série (Tabela 8 - 10 anos).

No que tange ao atendimento da população em idade escolar, por parte do sistema educacional público elementar para o ano de 1934, apresentamos as seguintes porcentagens: 7 anos - 87,20\%; 8 anos - 63,18\%; 9 anos - 76,35\%; 10 anos - 70,50\%; 11 anos - 67,34\% e 12 anos - 49,61\%. Ou seja, quase ao fim da gestão de Anísio Teixeira, o atendimento à população em idade escolar era bastante significativo, em termos percentuais. 
A democratização do ensino com Anísio Teixeira versus educação brasileira em te... Página 5 de 32

Outra variável analisada foi a distribuição dos alunos pelas séries do curso elementar, a qual espelha indiretamente o grau de promoção das crianças ao longo do sistema escolar (consultar Tabelas 11 a 13). Com base nos dados obtidos, podemos concluir que nos anos de 1930 e 1931 (Tabelas 11 e 12, respectivamente) a maior parte dos alunos concentrava-se na primeira série. Resumia-se, portanto, o curso elementar quase ao primeiro ano, com decréscimo nos anos subseqüentes como resultado provavelmente de um processo de evasão. Contudo, a partir de 1932 (Tabela 13), essa realidade começa a mudar - para este ano, a distribuição dos alunos entre as séries do ensino elementar é mais eqüitativa, o que indica o início de uma reversão do quadro anterior, com maior freqüência dos alunos, concomitantemente a uma provável diminuição da evasão escolar.

Finalmente, cabe também uma averiguação sobre a eficácia do sistema implantado, que pode ser aferida a partir dos índices de aprovação dos alunos na escola elementar diurna em relação aos anos de 1929 a 1934, sendo: 1929 - 43,13\%; 1930 44,10\%; 1931 - 49,74\%; 1932 - 60,39\%; 1933 - 65,78\%; 1934 - 65,93\%. Assim, de acordo com os dados obtidos, concluímos que houve um acréscimo bastante significativo na porcentagem de aproveitamento (avaliado ao final de cada ano letivo), relativo às crianças que foram promovidas de uma série para a outra. Supõe-se assim que ocorreu melhora no desempenho escolar das crianças para o período pesquisado.

Ressalve-se ainda que em sua gestão Anísio Teixeira promoveu um aumento do número de turnos escolares - de 1 e 2 para 3 turnos em algumas escolas. Além disso, foram instituídas classes de 40 alunos para um professor regente e aumento do número de escolas. Conseqüentemente, com o aumento do número

de turnos, escolas e alunos atendidos por professor, houve um acréscimo significativo no número absoluto de alunos que freqüentavam a escola primária a partir de 1931.

Portanto, concluímos que Anísio Teixeira efetivamente conseguiu colocar em prática boa parte de seus ideais democráticos em relação à educação, concretizados na ampliação do atendimento às crianças em idade escolar, aumento no atendimento por séries, diminuição da evasão escolar, aumento no aproveitamento escolar, entre outros aspectos.

Ao final deste item, é pertinente expor uma questão aparentemente marginal e isolada, mas ao mesmo tempo uma incógnita em relação ao tema estudado: sabemos que Anísio Teixeira manteve duros embates com setores privatistas da educação. Contudo, quando analisamos os dados expressos na Tabela 14 constatamos que houve um acréscimo de 30.516 matrículas, ou 39,93\% para o ano de 1934 em relação ao ano 
A democratização do ensino com Anísio Teixeira versus educação brasileira em te... Página 6 de 32

anterior no segmento das escolas particulares no Distrito Federal. Valor que em termos relativos, é bastante superior ao aumento no setor municipal para o mesmo ano, que foi de 20.606 matrículas, ou 16,26\%. É interessante notar ainda que tal acréscimo perdurou no segmento particular para o ano de 1935, em 5.608 e 5,24\%, em termos absolutos e percentuais, respectivamente.

Ainda, segundo a Tabela 15, pode-se concluir que o Distrito Federal isolado respondia por $17,85 \%$ do total das matrículas em território nacional para o segmento da educação particular em 1934 e 17,40\% em 1935, contra 13,61\% para o ano de 1933.

Dessa forma, soa estranho tal acréscimo no número de matrículas para o setor privado durante o final da gestão de Anísio Teixeira. Isso não significa dizer que tenha havido algum tipo de incentivo à educação privada, mas se Anísio Teixeira mantinha firme oposição ao privatismo, como tal segmento pôde lograr avanços tão significativos durante os anos de 1934 e 1935? Porém, por limitações de tempo infelizmente não pudemos nos deter nessa questão, a qual deve ser registrada como possível tema de pesquisa a ser investigado posteriormente.

\section{O capitalismo contemporâneo: características principais e emergência de um novo modo de regulação}

Paulani (2006) nos explica que o termo modo de regulação se refere à maneira pela qual o capitalismo assume diferentes formas de acumulação ao longo de sua existência enquanto sistema. Assim, ainda que movido pela mesma lógica - a busca pelo superlucro (SINGER, 1985), a valorização do valor (PAULANI, 2006) - o capitalismo assume características próprias em cada época histórica. Noutros termos, significa dizer que a produção e a reprodução do capital como relação social básica da sociedade não se manifesta da mesma forma nos diferentes modos de regulação que se sucedem.

Por sua vez, a mudança de um modo de regulação para outro se dá mediante a ocorrência de crises que são inerentes ao sistema. Ou seja, o processo de vir a ser do capitalismo é por princípio contraditório, sendo que uma das contradições essenciais que podemos apontar é a tendência à queda da taxa de lucro, à qual se associam as crises de acumulação. Harvey (2005, p.78), por seu turno, denomina-as de crises de sobreacumulação - a manifestação, de um lado, de excedentes de capital (em termos de mercado, moeda e capacidade produtiva) e de outro, de excedente de força de trabalho, lado a lado, sem que haja uma maneira de conjugá-los lucrativamente. Em outras palavras, seria a formação de um excedente de capital fixo que não pode ser utilizado lucrativamente (SINGER, 1991, p. 46).

Logo, entender o modo de regulação contemporâneo significa localizá-lo no cerne de uma crise que ocorre posteriormente ao ciclo áureo de crescimento mundial pós 
A democratização do ensino com Anísio Teixeira versus educação brasileira em te... Página 7 de 32

segunda guerra, relacionada com fatores depressivos de natureza tanto estrutural como conjuntural, os quais se associam de forma mutuamente dependente. Assim, sob o ponto de vista estrutural, citamos o esgotamento do modo de regulação fordista e a falência da política econômica fundamentada no keynesianismo. $E$ sob os aspectos conjunturais, citamos a crise da economia americana (queda da produtividade da indústria, superada pelo Japão e Alemanha; déficit fiscal decorrente dos gastos com a Guerra do Vietnã, corrida armamentista e espacial); os choques do petróleo (1973 e 1979); entre outros. Desse modo, trata-se de uma crise "[...] que tem como raiz a redução da taxa de lucro do setor manufatureiro, deslocando o capital para o setor financeiro [...]" (LEHER, 2001, p.56), mas que também está associada à derrocada do "[...] sistema de regulação nacional das economias capitalistas [...]" (SINGER, 1991, p.59)[3].

Portanto, com relação à crise advinda após a década de 1970, dois fatores merecem destaque: os processos de financeirização econômica e de reestruturação produtiva.

\subsection{A financeirização econômica}

Entendemos por financeirização o processo pelo qual o capital se valoriza sob os auspícios da denominada "ciranda financeira", mediante a obtenção de lucros decorrentes basicamente da especulação de ativos financeiros na forma de títulos (ações, debêntures[4], outros). Assim, esquematicamente, visualizamos abaixo o circuito que segue o capital industrial (adaptado de Guttmann, 1998):

capital inicial

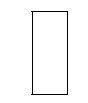

compra de mão de obra, instalações, equipamentos

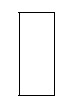

produção de bens e serviços (valorização via exploração do trabalho)

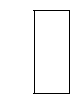

venda e obtenção de lucro

Todavia, o que acontece no capitalismo financeiro é que parte do capital é desviado do ciclo acima e transformado em títulos que são negociados nas bolsas de valores gerando dividendos, de modo que o dinheiro aplicado em títulos supera a base 
A democratização do ensino com Anísio Teixeira versus educação brasileira em te... Página 8 de 32

industrial / produtiva.

Até mais ou menos 1980, a esfera financeira era fundamental, mas suas transações fundavam-se nas operações lastreadas no capital industrial, sendo que é a partir dessa época que a financeirização domina o movimento geral do capitalismo mundial. Segundo Chesnais (1998, p.11):

O crescimento espetacular das transações financeiras foi um dos fatores mais significativos da década de 80 [do século XX] e já marcou os primeiros anos da década de 90 . Efetivamente, a esfera financeira representa a ponta de lança do movimento de mundialização da economia [...] é nessa esfera que as operações do capital envolvem os montantes mais elevados; é aí que sua mobilidade é maior.

Ou seja, o capitalismo atual é cada vez mais comandado pelo capital financeiro. Para ele converge e é drenada a riqueza produzida social e coletivamente por meio da atuação do Estado-Nação, das instituições econômicas internacionais, das principais empresas capitalistas e da esfera econômica em geral. É dessa forma que "[...] a mundialização dos capitais se realiza [...] mais com base no dinamismo do setor financeiro do que num desenvolvimento das forças produtivas." (LÖWY; BENSAÏD, 2000, p.29).

Já o termo mundialização financeira é empregado por Chesnais (1998, p.12) e designa as ligações entre os sistemas monetários e os mercados financeiros em nível nacional e internacional, resultantes da liberalização e desregulamentação do mercado à livre circulação do capital, o que propiciou a emergência de um espaço financeiro mundial. Contudo, esse espaço é fortemente hierarquizado e centralizado. Seu centro nervoso é o sistema financeiro dos EUA, em função principalmente do volume das transações internacionais que ocorrem com base no dólar: $2 / 3$ do comércio mundial; 3/4 dos créditos internacionais; $80 \%$ das transações no mercado de câmbio internacional. Ademais, os bancos americanos são os maiores do mundo (BRUNHOFF, 1998).

Harvey (2005) afirma que o sistema financeiro está baseado na tríade Wall Street - Tesouro Americano - FMI/Banco Mundial, que por sua vez é a base do tripé formado juntamente com os principais centros financeiros da Europa (Alemanha, França, Inglaterra) e Ásia (Japão, China). É no interior desse espaço que são feitos os negócios e de onde partem as decisões estratégicas sobre a finança mundializada que afetam a humanidade como um todo. Porém, é um sistema sem supervisão, sem controle e caótico, pois é praticamente impossível acompanhar e antecipar os fluxos de capital e financeiro em sua totalidade.

A unidade dos mercados é assegurada pelos operadores financeiros interligados pela tecnologia (telecomunicações, informática), com base na liberalização e interligação do sistema em tempo real, cujas decisões são tomadas pelos gestores das 
A democratização do ensino com Anísio Teixeira versus educação brasileira em te... Página 9 de 32

carteiras mais importantes e mais internacionalizadas. Os investimentos em capital fictício são muito mais concentrados e muito mais voláteis e crescem mais do que os investimentos na produção, PIB mundial ou comércio exterior, sendo que a parcela mais elevada das transações financeiras ocorre no campo fechado das instituições financeiras e não tem nenhuma contrapartida em termos de intercâmbio de mercadorias e serviços. É o caso de 1,4 trilhões de dólares dos quais apenas 5 a $8 \%$ têm correspondência num lastro real (!).

Trata-se de uma massa de dinheiro elevada à esfera financeira que se valoriza ficticiamente, inchando o montante nominal dos ativos financeiros, sendo que hoje parte bastante significativa dessa esfera se dá pela absorção do superávit primário[5] dos países inicialmente endividados com a crise da dívida externa das décadas de 70-80. A base desta riqueza é o trabalho social, sugado na forma de impostos, contribuições e outras formas de espoliação via principalmente instituição Estado (essa é a origem e o motivo da prioridade absoluta destinada à composição do superávit primário da economia brasileira).

Além do superávit primário, a política de elevação da taxa básica de juros da economia (o Brasil tem a mais alta taxa do mundo) está subordinada à necessidade dos ganhos obtidos pela compra dos títulos da dívida pública remunerados por essa taxa no mercado financeiro (contrariamente ao que se apregoa sobre a falácia da necessidade do controle da inflação).

Fundado no Consenso de Washington (CW) e por meio de uma arquitetura financeira internacional, esse sistema serve aos interesses de uma burguesia transnacional, alimentando os lucros de classes rentistas que ganham com a especulação financeira[6]:

Surgiu alguma espécie de classe capitalista transnacional [...]. Essa classe recorreu como sempre aos Estados Unidos para ter protegidos seus valores de ativos e seus direitos de propriedade e posse em todo o globo. [...] Os capitais concentrados nos mercados europeu e japonês podiam tirar sua lasca, o mesmo ocorrendo com toda classe rentista que se posicionasse corretamente no âmbito da matriz das instituições capitalistas. Crises da dívida podiam abalar o Brasil e o México, crises de liquidez podiam destruir as economias da Tailândia e da Indonésia, mas elementos rentistas desses países puderam não só preservar seu capital como na verdade melhorar sua própria posição interna de classe. As classes privilegiadas tiveram condições de se proteger em guetos dourados em Bombaim, em São Paulo e no Kuwait, ao tempo em que colhiam os frutos de seus investimentos em Wall Street. (Harvey, 2005, p.151)

\subsection{A reestruturação produtiva}

As conseqüências da proeminência do capital financeiro são várias: desregulamentação dos mercados de capitais e mercadorias e das relações de trabalho; queda da taxa de investimentos e da produção industrial; aumento da taxa de 
A democratização do ensino com Anísio Teixeira versus educação brasileira em t... Página 10 de 32

desemprego; aumento das taxas de juros; endividamento do setor público/privado; favorecimento das instituições bancárias; privatização do Estado, com conseqüente diminuição dos investimentos nos setores sociais (GUTTMANN, 1998).

Acrescente-se que a centralização do capital atingiu intensidade inédita, com a constituição de grandes massas de capitais que dominam vários setores da economia. Concomitantemente, o processo de desregulamentação propiciou o movimento de aquisições e fusões entre empresas, acompanhadas da reestruturação produtiva e organizacional. Assim, a "vingança do capital contra o trabalho" se dá porque "[...] a crise que comprimia as margens de lucro tinha de ser amenizada com redução de gastos com pessoal e flexibilização da força de trabalho, uma vez que as garantias sociais conferidas a esta última tornavam-se agora um custo insuportável e inadmissível." (PAULANI, 2006, p.77)

Com a intensificação da transnacionalização e oligopolização do capital e das empresas, o mundo todo é considerado cenário propício para a produção e o investimento. Dessa forma, se entre 1950 e 1970, as empresas multinacionais montavam plantas industriais na periferia do sistema, porque precisavam de novos mercados,

[...] na década de 1990 o que marca a estratégia dos grupos transnacionais é a busca permanente de se livrar dos investimentos de longa duração, ganhando flexibilidade para explorar oportunidades lucrativas. Isso faz com que as grandes corporações, num movimento desenfreado, operem "deslocalizações" de suas atividades, inclusive de sua capacidade produtiva, para qualquer lugar do planeta, sempre que isso for visto como uma possibilidade de redução de custos. Com isso, muitas vezes, as atividades transferidas são aquelas mais simples e rotineiras, como as operações de montagem, enquanto as etapas mais complexas do processo produtivo (concepção do produto, definição do design, pesquisa e tecnologia, marketing) terminam, na maior parte dos casos, não sendo externalizadas. (PAULANI, 2006, p.84-5)

Tal tipo de industrialização apenas coloca os países periféricos num patamar inferior em relação ao desenvolvimento científico, tecnológico e industrial. Além disso, os atrativos para instalação das unidades fabris contam com incentivos fiscais, desoneração de tributos e enfraquecimento do pólo trabalho de um modo geral. Em verdade, o modelo de divisão internacional do trabalho atual tem por objetivo unicamente a intensificação da exploração do trabalho pela extração do valor por meio da criação de mais valia absoluta.

Evidentemente, o sistema em sua totalidade traz conseqüências drásticas e atinge diretamente o cenário macro e microeconômico mundial, com destaque para os países ditos emergentes, os quais são incorporados ao processo de mundialização financeira, mediante uma série de medidas, das quais podemos citar a securitização da dívida pública; a liberalização e desregulamentação dos mercados financeiro e de mercadorias; incentivo aos processos de precarização e terceirização do emprego; queda 
A democratização do ensino com Anísio Teixeira versus educação brasileira em t... Página 11 de 32

real do salário; enfraquecimento dos sindicatos; imposição do CW, entre outras.

Em vista do exposto, cabe então questionar: quais implicações e determinações desse processo no Brasil? Qual o papel desempenhado pelo Brasil no cenário que se apresenta?

\section{O Brasil no contexto do capitalismo contemporâneo[7]}

O que aconteceu foi a implantação de uma política macroeconômica fundada basicamente na crença absoluta da supremacia do mercado na regulação da economia e no estabelecimento de uma agenda relativa ao "Estado Mínimo", ambos consubstanciados numa doutrina consentânea com os influxos e as necessidades ditados pelo modo de regulação que se instaurou a partir de 1970 - a doutrina neoliberal.

No tocante aos ditames do capital financeiro, houve uma pressão crescente pela liberalização e desregulamentação dos mercados financeiros e de capitais; pela definição de regras de política monetária que favorecessem os credores, rentistas e todos os que auferissem lucros na ciranda financeira; pela redefinição do papel do Estado (controle de gastos, privatização de empresas estatais, atuação restrita no mercado, etc.). Tal "agenda", aplicada primeiramente[8] na Inglaterra com Margareth Thatcher (1979 -1990) e depois nos EUA com Ronald Reagan (1981 - 1989), posteriormente espraiou-se por praticamente todos os outros países capitalistas centrais, vindo depois a ser aplicada nos países da América Latina, do "terceiro mundo", ou aqueles inicialmente endividados com a crise da dívida externa da década de 1980, mediante o CW.

Assim, no Brasil, a submissão aos imperativos do dito consenso foi quase absoluta, iniciando-se com Collor de Mello até Lula da Silva, mas com alguns requintes de sofisticação: nós assumimos a condição de "economia emergente" na posição de plataforma de valorização financeira internacional, num plano desenhado e implementado ao longo de anos e que vem se aprofundando ininterruptamente.

No que se refere ao papel do Brasil na divisão internacional do trabalho, a assunção de condição periférica e secundária em relação à industrialização nos levou a um processo de "desindustrialização" em que ocorreram mudanças importantes nas empresas que atuavam no Brasil, mediante a adoção de novos programas de gestão e produção, reorganização do trabalho, inovação tecnológica, informalização, precarização do emprego e aumento do desemprego. Assim, as grandes empresas transnacionais conseguiram adequar-se às mudanças em curso muitas vezes às custas da fragilização do pólo trabalho. De outro lado, na ponta da cadeia produtiva operou-se o retraimento, fechamento e informalização do setor produtivo.

Veja-se o exemplo das empresas transnacionais dos segmentos automotivo, de 
A democratização do ensino com Anísio Teixeira versus educação brasileira em t... Página 12 de 32

computadores, celulares, áudio-tv, conforme já citado anteriormente: são instalados módulos de produção em vários locais do mundo, em que se produzem partes dos componentes das mercadorias de modo a baratear os custos, que depois são montadas em algum país emergente da Ásia ou da América Latina. Por outro lado, as matrizes das empresas desenvolvem as atividades mais "nobres" (marketing, design, pesquisa, desenvolvimento tecnológico/novos materiais, etc.).

Simultaneamente, houve um processo de "reprimarização" da economia brasileira com a produção de commodities (alta escala de produção, baixo preço unitário, simplificação tecnológica, baixo valor agregado, ênfase na exportação). Desse modo, a produção industrial foi sendo em parte substituída por produtos importados. E na medida em que a estabilidade monetária aconteceu (na década de 1990) associada à maior oferta de produtos e ao ingresso de recursos externos, o PIB sofreu uma recomposição, na qual o setor secundário da economia perdeu participação relativa (POCHMANN, 2006, p.118).

À guisa de uma síntese provisória, o raciocínio de Pochmann (2006, p.114) é esclarecedor: "[...] está em curso um novo modelo econômico, com baixa taxa de expansão produtiva, forte vinculação à financeirização da riqueza e à revalorização do setor primário exportador [...]".

Tal quadro completa-se com a adoção de uma política social de base meramente compensatória, cujo objetivo não é a redistribuição de renda, a socialização da propriedade privada ou a reconfiguração das classes sociais, mas apenas a contenção da miséria e a garantia da sobrevivência em níveis minimamente suportáveis para a maioria da população.

\section{Democratização do ensino com Anísio Teixeira versus educação brasileira em tempos de neoliberalismo}

De acordo com nossa proposta de estudo, iniciamos agora o cotejo dos dois momentos históricos (a democratização do ensino obtida com Anísio Teixeira em 1931 1935 e a situação brasileira no atual modo de regulação) examinando a concepção tão cara a Anísio Teixeira, segundo a qual a educação é um bem público e portanto algo que deveria ser subvencionado pelo Estado. Contra esse princípio, opõem-se tanto a tendência geral à mercantilização de pessoas e coisas (que é inerente ao capitalismo, mas que na época atual assume seu paroxismo e já havia sido denunciado por Marx, além de outros autores mais atuais, tais como Harvey, 2005 e Wood, 2003), quanto a privatização do público, os quais não são processos paralelos, mas mutuamente imbricados.

Com relação à mercantilização, ocorre que no modo de regulação atual tudo pode ser objeto de lucro esteja onde estiver, independentemente da sua condição de ser um serviço, uma mercadoria, ou algum dia ter sido considerado um direito social, numa 
A democratização do ensino com Anísio Teixeira versus educação brasileira em t... Página 13 de 32

visão imediatista de ganho, ao mesmo tempo em que há uma retração em relação aos investimentos de longo prazo em capital fixo. Assim, no caso da educação, esta se transforma numa mercadoria stricto sensu como fonte de valorização do capital, mediante as relações de compra e venda de força de trabalho e compra e venda da própria mercadoria educação.

Seguindo tal perspectiva, a educação no Brasil (e no mundo) tornou-se um negócio extremamente rentável: o mercado da educação privada no Brasil faturou no ano de 2003 o total de 35,5 bilhões de reais, sendo que de todos os níveis, o ensino superior foi o mais lucrativo, faturando 14,9 bilhões, seguido pelo ensino fundamental, com 13,3 bilhões (ESTRANGEIROS..., 2003). Sob a mesma ótica, a Faculdade Anhembi Morumbi de São Paulo teve $51 \%$ de sua participação comprada por um grupo educacional americano (o Grupo Laureate), no valor de R\$ 158 milhões ("AMEAÇA"..., 2006; GOIS; TAKAHASHI, 2005). Em transação similar, a Anhangüera Educacional, do interior de São Paulo, recebeu investimentos da ordem de US\$12 milhões do Banco Mundial, por meio de seu braço privado, a International Finance Corporation (IFC) (BANCO..., 2006).

Num desdobramento do esquema de valorização do capital, a então mercadoria educação, ao gerar grande volume de dinheiro e em função do processo de financeirização, também se torna uma forma de ganho no mercado financeiro. Recentemente, a Universidade da Cidade de São Paulo obteve autorização para emissão de $R \$ 40$ milhões em debêntures. Por sua vez, a Universidade Luterana do Brasil e a UniverCidade do Rio de Janeiro captaram respectivamente $R \$ 174$ milhões e $R \$ 22$ milhões com a mesma operação (CONTRA ..., 2006; UNIVERSIDADES ..., 2006).

No caso daquilo que estamos denominando de privatização do público, o Estado é administrado como um grande negócio, no sentido de garantir sob várias formas e níveis o processo de acumulação do capital. Para tanto, foi preciso arquitetar e implementar uma política macroeconômica que combinou de forma perversa 0 enxugamento dos gastos públicos, cortes nos gastos sociais, aumento da carga tributária e manutenção de elevada taxa de juros.

Segundo dados de Duarte (2007), de 2003 a 2006 o Brasil desembolsou R\$ 590,639 bilhões (!) para pagamento dos juros da dívida, os quais superam em quase $\mathrm{R} \$ 90$ bilhões o volume total dos investimentos previstos até 2010 para o Programa de Aceleração do Crescimento e equivale a mais de 13 vezes os gastos do governo com saúde no ano de 2006. Ademais, o superávit primário durante o período de 2003 a 2006 alcançou a cifra de $\mathrm{R} \$ 330,935$ bilhões, variando entre $4,25 \%$ e $4,83 \%$ do PIB. Como não poderia deixar de ser, a área social no orçamento federal tem apresentado regressão ao longo do tempo - entre 2001 e 2004, a diminuição foi de aproximadamente 8,5\% de redução real por habitante. No caso da educação e cultura, houve redução de 9,7\% para o 
A democratização do ensino com Anísio Teixeira versus educação brasileira em t... Página 14 de 32

mesmo período (POCHMANN, 2006). Assim, nós convivemos, de um lado, com um brutal desvio da riqueza social que alimenta o padrão de acumulação fundado na financeirização e de outro, com a estagnação econômica, o endividamento público, a retração dos investimentos e dos gastos sociais.

Foge ao escopo deste ensaio um estudo aprofundado do tema, contudo, cabe assinalar alguns aspectos do problema. Um deles é a forma como o Estado, sob a inspiração do modelo neoliberal subvenciona de maneira desabrida o setor privado da educação superior no Brasil, sendo o PROUNI (Programa Universidade para Todos) o exemplo mais expressivo[9]. No caso da utilização do fundo público em prol do ganho de setores privados ligados à educação, é sob os auspícios do aparato estatal que parte significativa desse tipo de lucro se consuma, seja para a compra de livros, alimentos, pagamento para prestação de serviços, entre muitos outros. De acordo com o artigo FNDE... (2006), o Fundo Nacional de Desenvolvimento da Educação (FNDE/MEC) vai gastar R\$ 456,7 milhões para compra de livros, apenas no ano de 2007. Sobre o mesmo assunto, o artigo LIBERADOS ... (2006) informa que o FNDE, por meio de programas como o Programa Nacional de Alimentação Escolar, destinou cerca de $R \$ 145$ milhões, além dos recursos do salário educação, no montante de $\mathrm{R} \$ 485$ milhões.

De acordo com o exposto no item 1 do presente estudo, Anísio Teixeira efetivamente logrou obter a democratização do ensino, o que é comprovado pelo aumento do número de matrículas, acesso ao sistema escolar, maior eficiência do sistema, melhoria da qualidade do ensino etc. Contudo, o que observamos é que se na atualidade ocorreu a universalização quase que total do acesso à escola, tal universalização convive tanto com a seletividade extrema quanto com a brutal degradação da qualidade do ensino - não é exagero afirmar que a educação no Brasil é uma das piores, quando comparada com os países da América Latina, alguns países ditos emergentes (Índia, China, Rússia, Coréia do Sul) e países da Organização para Cooperação e Desenvolvimento Econômico (OCDE). A título de ilustração, sugerimos acompanhar os dados abaixo:

- segundo o Indicador Nacional de Alfabetismo Funcional (INAF), pesquisado em meados de 2005, apenas $25 \%$ dos brasileiros entre 15 e 64 anos dominam a leitura e a escrita (ESTUDO..., 2005). Ainda, para Cafardo (2005), 75\% da população apresentam dificuldade para ler e escrever, sendo que tal porcentagem inclui os analfabetos absolutos $(7 \%)$ e os analfabetos funcionais (68\%). Sobre o tema, com base na síntese de indicadores para 2005, divulgada pelo Instituto Brasileiro de Geografia e Estatística (IBGE) para os brasileiros com 15 anos ou mais, a taxa de analfabetismo era de $11 \%$, ou 14,9 milhões de pessoas, índice comparável ao da África do Sul (12,9\%). Tratando-se do analfabetismo funcional, a conclusão é de que aproximadamente um em quatro brasileiros está nessa condição (MENEZES; LOUVEN, 2006); 
A democratização do ensino com Anísio Teixeira versus educação brasileira em t... Página 15 de 32

- segundo o Sistema Nacional de Avaliação da Educação Básica (SAEB), no ano de 2003 , cerca de $55 \%$ dos alunos da $4^{a}$ série do Ensino Fundamental apresentaram desempenho crítico ou muito crítico em Língua Portuguesa, sendo $26,8 \%$ dos alunos da $8^{\text {a }}$ série do Ensino Fundamental e $38,6 \%$ dos alunos da $3^{\text {a }}$ série do Ensino Médio (ALUNOS..., 2006);

- de acordo com os dados do Programa Internacional para Avaliação dos Estudantes (PISA), que é um sistema de avaliação criado pela OCDE, cujo objetivo é avaliar a qualidade dos sistemas educacionais de 60 países, no ano de 2000 o Brasil ficou em último lugar no ranking geral no quesito leitura e penúltimo na prova de desempenho em matemática, no ano de 2003 (PISA..., 2006);

- sobre os índices de conclusão dos estudantes brasileiros (considerados muito baixos) Weber (2006) assevera que de cada cem alunos que ingressaram na 1a série em 1997, apenas 53 concluíram a 8ª série em 2004;

- sobre o acesso à educação formal, com base num estudo do Instituto de Pesquisa Aplicada (IPEA) realizado em 2005, Weber (2007) informa que apenas 45\% dos jovens de 15 a 17 anos freqüentavam o ensino médio e 11\% da população de 18 a 24 anos freqüentava a universidade. Ainda, sobre o tema, somente três em cada 100 alunos que se matriculam no ensino formal conseguem ter acesso à uma Instituição de Ensino Superior pública ao final do ciclo de escolarização e nós chegamos ao século XXI com a População Economicamente Ativa do Brasil com uma escolaridade média de 4 anos (informação verbal)[10].

Em nossa opinião, a má qualidade da educação (bem como a má qualidade dos serviços prestados pela saúde e pela assistência e previdência social) só pode ser explicada quando considerada como pertencente ao projeto político, social e econômico, que no final das contas coloca o Brasil entre as dez maiores economias do mundo. Mas que tipo de economia? Uma economia que nos posiciona como plataforma de valorização do capital financeiro e exportadora de produtos primários, ao mesmo tempo em que constrange os setores sociais ao mínimo de sobrevivência (Bolsa Família), ao mínimo de Educação (Fundef, Fundeb), ao mínimo da saúde, dos direitos sociais, etc.

Para Oliveira (2006) ocorre que no Brasil o Estado e o Parlamento perderam a capacidade de arbitrar sobre as grandes questões nacionais, pois tornaram-se reféns dos imperativos do capital financeiro e transnacional. No caso do primeiro, pagam-se bilhões em juros da dívida pública e corre-se atrás da miragem do equilíbrio fiscal, fazendo-se política econômica com a moeda. No segundo caso, os sucessivos escândalos envolvendo o Congresso expressam a forma de relacionamento entre os poderes da república, em que a garantia das benesses é a prioridade. 
A democratização do ensino com Anísio Teixeira versus educação brasileira em t... Página 16 de 32

No que se refere à posição que o Brasil assume na divisão internacional do trabalho, qual seja, uma posição secundária e periférica, as conseqüências para a educação são dramáticas. Concordamos com Paulani (2006), quando a autora afirma que num mundo de aceleração no desenvolvimento e difusão de novos conhecimentos e tecnologias (nanotecnologia, robótica, informática, telecomunicações, desenvolvimento de novos materiais, biotecnologia, engenharia genética, etc.) e de crescimento da produtividade do trabalho, nosso país engatou a marcha à ré. A explicação para isso é que a informação, a ciência e a tecnologia não são universalizáveis, estando hoje muitas vezes protegidas na forma de caixas pretas e patentes, o que exige um esforço de investimento dos países periféricos que está além de suas possibilidades. Assim, a nós resta a produção de commodities e de bens de consumo descartáveis e efêmeros que podem ser copiados.

Portanto, esse tipo de demanda não requer uma educação ou uma produção de conhecimento de alto nível e sofisticada: uma educação superior simplificada, aligeirada, de nível secundário e que não requer altos investimentos em ciência e tecnologia é satisfatória. Com relação ao ensino fundamental, o quadro também é pouco alentador, pois uma educação minimalista e focalizada é suficiente para cumprir com as responsabilidades sociais do modelo neoliberal. Nesse sentido, ler, escrever, somar, subtrair, multiplicar, dividir, minimamente, enquadra-se de modo apropriado ao projeto social adotado.

Sob tal perspectiva, é muito significativa a atuação de organismos como o Banco Mundial, com relação ao incentivo à universalização da educação básica, bem como às políticas de focalização. Podemos supor que tais medidas estão associadas também a mecanismos de contenção de conflitos e convulsões sociais, na medida em que: a) retardam a disputa e o ingresso das pessoas num mercado de trabalho cada vez mais restrito e competitivo; b) num movimento simultâneo, mantêm a população mais "propícia" ou "exposta" à violência (crianças e jovens em idade escolar) e aos conflitos sociais "ocupada" numa atividade, que ao mesmo tempo incute a disciplina e a incorporação de regras e condutas socialmente aceitáveis (FRIGOTTO, 2006).

É de conhecimento geral que a escola cumpre e cumpriu um papel político fundamental nas sociedades humanas e que dificilmente se pode imaginar uma instituição que detenha os mesmos poderes que a escola na salvaguarda dos processos de controle social, legitimação, ideológicos, reprodução da força de trabalho, entre outros. Não é à toa a afirmação de Harvey (2005, p.118), para quem a educação é um setor do capitalismo, ou Mandel (1985, cap.12), para quem a educação é a responsável pela reprodução da força de trabalho.

\section{CONSIDERAÇÕES FINAIS}


A democratização do ensino com Anísio Teixeira versus educação brasileira em t... Página 17 de 32

Nestas Considerações Finais, ao discorrermos sobre os limites e as possibilidades do pensamento e da ação de Anísio Teixeira, não se trata de analisar a pessoa, mas as múltiplas determinações existentes entre a realidade e os processos estruturais do sistema. Sob esta ótica, enfatizamos a relação desenvolvimento das produtivas $X$ relações sociais de produção - o que ocorre é que ao longo do processo histórico do desenvolvimento das forças produtivas houve momentos específicos nos quais de fato ocorreu expansão do sistema educacional formal (por exemplo, os trinta anos posteriores à segunda guerra mundial)[11].

Anísio Teixeira efetivamente promoveu avanços na área educacional, como Secretário da Educação e Cultura do Distrito Federal nos anos de 1931-1935, mas situado num momento de transição de uma sociedade agrário-exportadora para urbano-industrial. Ou seja, a educação assumiu o caráter de um investimento de médio/longo prazos, na medida em que o capitalismo da época necessitava de mão de obra ao desenvolvimento das forças produtivas.

Ademais, não seria exagero afirmar que Anísio Teixeira foi o idealizador e o precursor de muitas medidas adotadas atualmente na área educacional (a municipalização do ensino, os Conselhos de Educação, o Fundef, etc). Todavia, a contradição desenvolvimento das forças produtivas $X$ relações sociais de produção, em função da necessidade férrea e implacável da eterna produção e reprodução do capital, acabam por submeter todas as esferas da realidade à sua lógica. Nesse sentido, muito do que foi um avanço em Anísio, torna-se um retrocesso: os Conselhos de educação (veja-se por exemplo o atual Conselho Nacional de Educação); a universalização do acesso à escola (que depois de alcançada, é solapada pela péssima qualidade do ensino); a municipalização, em que a escola detém uma autonomia aparente (autonomia políticoadministrativa em parte, mas não econômica).

Aqui, a explicação de Fernandes (1966, p.75) num livro clássico é esclarecedora: o pensamento republicano espraiou-se pela educação, quanto à necessidade de democratizar o ensino como condição para a universalização dos direitos fundamentais e como condição para a prática da cidadania e da democracia. Assim, os educadores da época conseguiram catalisar esforços e ações nesse sentido, com ações efetivas, em torno do modelo da escola nova. Contudo, a exigência da educação primária obrigatória, universal e gratuita e os problemas da educação popular não foram resolvidos nem enfrentados. Pelo contrário, o ensino sofreu solapamento voluntário, a formação de professores e a expansão da rede de ensino foram afetados. Ou seja, houve um avanço, sucedido de um retrocesso, em cima do que fora conquistado.

Outro aspecto a considerar é como algumas mazelas do sistema educacional, mutatis mutandis, se perpetuam ao longo de décadas. Referimo-nos à seletividade do 
A democratização do ensino com Anísio Teixeira versus educação brasileira em t... Página 18 de 32

sistema: de uma educação oligárquica, passamos para uma educação dualista e agora, minimalista e focalizada. Mais uma vez, Fernandes (1966) retratou fielmente uma realidade passada que se mantém no presente:

[...] Trata-se, literalmente, de um sistema educacional coerente com o antigo regime senhorial brasileiro, acrescido de algumas deformações, especialmente na estrutura de base e no alargamento da estrutura intermediária. (p.24)

$[\ldots]$

Desse ângulo, não deixa de ser um paradoxo a estranha contradição que impera no Brasil: enquanto propugnamos por "desenvolvimento econômico acelerado" e por uma "política de desenvolvimento", mantemos a educação como um privilégio social e como um fator estático ou neutro. (p.XXI)

Como entender então a existência de problemas estruturais que persistem ao longo de décadas? O que supomos existir é um projeto implementado e perpetuado pelas nossas elites e classes dirigentes, num modelo que integra idiossincrasias e interesses internos com os movimentos e processos históricos do sistema capitalista, num mix cruel do que Harvey (2005) denomina de acumulação via espoliação e coerção consentida, em que ambos se complementam. Ou seja, de um lado, a acumulação se vale de todos os expedientes possíveis (independentemente de qualquer dimensão ética ou moral): 0 roubo, a fraude, a corrupção, a força, a opressão, a pilhagem, o suborno, a guerra, que no final das contas são todos justificáveis em prol da garantia da acumulação incansável do capital. De outro lado, tais mecanismos só podem obter êxito na medida em que existe o consentimento à coerção, ou seja, o compadrio, a subserviência, a submissão, a coalizão.

Tal panorama revela uma situação muito mais conservadora do status quo do que transformadora. Sendo assim, no que concerne à escola, as idéias que defendem uma perspectiva de afrontamento à opressão, de construção de um pensamento combativo e crítico e de transformação da realidade não têm se manifestado concretamente.

Com tudo isso, não queremos dizer que o denodo e a dedicação de pessoas como Anísio Teixeira não têm valor. Muito pelo contrário - os embates em prol da conquista pela democracia e dos avanços em direção a uma educação popular e universal só podem e devem acontecer no bojo do sistema capitalista. Contudo, não podemos nos iludir: os avanços ou retrocessos decorrentes dessas lutas ocorrem no solo da dinâmica do processo de acumulação do capital, o qual, em última instância, dita os limites e as possibilidades dos ganhos sociais. A nós resta a possibilidade de compreender 0 movimento do real e atuar nas contradições do sistema de modo a obtermos ganhos relativos em termos dos interesses das classes sociais antagônicas ao capital.

Para Leher (2001) o termo democracia padece de uma complexidade e polissemia que se modifica em face das mudanças históricas e estruturais. Ou seja, a 
A democratização do ensino com Anísio Teixeira versus educação brasileira em t... Página 19 de 32

democracia não pode ser assumida de forma absoluta e imutável, na condição de manifestação dos interesses da maioria. É nesse sentido que Losurdo (2004) afirma que a democracia, enquanto manifestação de fato, é algo muito frágil e pouco sustentável, pois o termo sofreu grandes transformações ao longo do tempo, em que ocorreram tanto "avanços" (a conquista do sufrágio universal masculino e feminino, a luta contra o apartheid na África do Sul, a conquista dos direitos dos negros nos EUA, etc.), quanto "retrocessos" (o nazi-fascismo, as ditaduras na América Latina, as ofensivas bélicas dos EUA no Vietnã e Oriente Médio, a ofensiva bélica de Israel contra a Palestina, etc.). Ainda, segundo o raciocínio do autor, há um claro retrocesso em relação à condição democrática nos tempos do neoliberalismo.

Por conseguinte, contrariamente ao que apregoa a doutrina neoliberal, que defende a disjunção entre as dimensões política e econômica do real (HAYEK, 1998), entendemos que só é possível discutir o conceito de democracia mediante uma perspectiva macro estrutural, sob a qual se funda um tipo de experiência democrática que prevalece num dado momento histórico, associado a um modo de produção específico.

Dessa forma, concluímos que, se apartados da realidade concreta da existência, termos como democracia e público no sistema capitalista são apenas conceitos que não têm sentido real, mas apenas formal. Em sentido lato e universal, a democracia não existe e talvez nunca tenha existido no sistema capitalista, posto que a mesma não pode se referir apenas à política ou à economia. É um engodo pensar que o exercício democrático se limita ao direito de votar e ser votado, o que acontece num intervalo regular de anos. Tal raciocínio mascara a ditadura econômica à qual estamos submetidos, bem como a violência tanto escamoteada quanto explícita, dependendo das circunstâncias e do lócus social daqueles que a sofrem: a luta de classes; a expropriação no trabalho; a concorrência pela garantia da sobrevivência, seja no mercado de trabalho formal ou informal; a guerra civil aberta em que vivemos.

Portanto, o modo de produção capitalista impõe uma impossibilidade estrutural: não há como existir uma esfera pública que garanta educação, saúde, previdência e assistência social de qualidade num nível universal.

\section{REFERÊNCIAS BIBLIOGRÁFICAS}

ALUNOS têm dificuldades em leitura. Correio do povo, Porto Alegre, 28 abr. 2006. Disponível em: <http://www.clippingeducacional.com.br>. Acesso em: 29 abr. 2006.

"AMEAÇA" estrangeira? Portal Universia, [S.I.], 27 abr. 2006. Disponível em: <http://www.clippingeducacional.com.br>. Acesso em: 28 abr. 2006.

ARCARY, Valério. Cinco observações sobre a crise da educação pública para uma estratégia revolucionária. In: Cadernos de Debates ILAESE, São Paulo, nov.2005, p.41- 
A democratização do ensino com Anísio Teixeira versus educação brasileira em t... Página 20 de 32

51.

BANCO Mundial investe US\$12 mi em faculdades. Portal Aprendiz, [S.I.], 31 jul. 2006. Disponível em: <http://www.clippingeducacional.com.br>. Acesso em 01 ago. 2006.

BATISTA, Paulo Nogueira. O consenso de Washington. São Paulo: PEDEX, 1995. (Coleção Cadernos da Dívida Externa).

BRASIL. Instituto Brasileiro de Geografia e Estatística. Anuário Estatístico do Brasil, 1937, v.3. $\overline{1938, v .4 .}$

Instituto Brasileiro de Geografia e Estatística. Anuário Estatístico do Brasil,

BRUNHOFF, Suzanne de. A instabilidade financeira internacional. In: CHESNAIS,

François. (Coord). A mundialização financeira. São Paulo: Xamã, 1998. p.35-59.

CAFARDO, Renata. 75\% dos brasileiros não sabem ler direito. Agência Estado, São Paulo, 08 set. 2005. Disponível em: <http://www.clippingeducacional.com.br>. Acesso em: 08 set. 2005.

CHESNAIS, François. Introdução geral. In: CHESNAIS, François. (Coord). A mundialização financeira. São Paulo: Xamã, 1998. p.11-33.

CONTRA a crise, universidades lançam debêntures. Portal Último Segundo, [S.I.], 26 jul.2006. . Disponível em: <http://www.clippingeducacional.com.br>. Acesso em: 26 jul.2006.

DUARTE, Patrícia. Meio trilhão em juros. O Globo, Rio de Janeiro, 01 fev. 2007. Economia, p.23.

ESTRANGEIROS querem comprar universidades. O Estado de São Paulo, São Paulo, 20 ago. 2003. Disponível em: <http://www.clippingeducacional.com.br>. Acesso em: 20 ago. 2003.

ESTUDO aponta que só $25 \%$ dos brasileiros dominam leitura e escrita. Folha Online, São Paulo, 08 set. 2005. Disponível em: <http://www.clippingeducacional.com.br>. Acesso em: 08 set. 2005.

FERNANDES, Florestan. Educação e sociedade no Brasil. São Paulo: Dominus, EDUSP, 1966.

FIORI, José Luis. O consenso de Washington. Disponível em:

<http://www.pdt.org.br/internacional/washington.asp>. Acesso em: 30 jan. 2007.

FNDE compra 102,5 milhões de livros didáticos para 2007. Agência Estado, São Paulo, 04 set.2006. Disponível em: <http://www.clippingeducacional.com.br>. Acesso em: 04 set.2006.

FRIGOTTO, Gaudêncio. A produtividade da escola improdutiva. 8.ed. São Paulo: Cortez, 2006.

GOIS, Antônio; TAKAHASHI, Fábio. Grupo dos EUA compra a Anhembi Morumbi, [S.I.], 02 
A democratização do ensino com Anísio Teixeira versus educação brasileira em t... Página 21 de 32

dez.2005. Disponível em: <http://tools.folha.com.br>. Acesso em: 03 dez.2006.

GORENDER, Jacob. Estratégias dos Estados nacionais diante do processo de globalização. Estudos Avançados, São Paulo, v.9, n.25, p.93-112, 1995.

GUTTMANN, Robert. As mutações do capital financeiro. In: CHESNAIS, François. (Coord). A mundialização financeira. São Paulo: Xamã, 1998. p.61-96.

HARVEY, David. O novo imperialismo. São Paulo: Loyola, 2005.

HAYEK, Friedrich August von. Os princípios de uma ordem social liberal. In: CRESPIGNY, A. de., CRONIN, J. Ideologias políticas. 2.ed. Brasília: Ed. UnB, 1998. p.47-63.

LEHER, Roberto. Tempo, autonomia, sociedade civil e esfera pública: uma introdução ao debate a propósito dos "novos" movimentos sociais na educação. In: GENTILI, Pablo; FRIGOTTO, Gaudêncio (orgs.). A cidadania negada. São Paulo: Cortez; Buenos Aires, Argentina: CLACSO, 2001. p.145-176.

LIBERADOS recursos do salário-educação e da merenda escolar. Portal MEC, [S.I.], 11 set.2006. Disponível em: <http://www.clippingeducacional.com.br>. Acesso em: 11 set.2006.

LOSURDO, Domenico. Democracia ou bonapartismo. Rio de Janeiro: Editora UFRJ/Editora UNESP, 2004.

LÖWY, Michael; BENSAÏD, Daniel. Marxismo, modernidade e utopia. São Paulo: Xamã, 2000.

MANDEL, Ernest. O capitalismo tardio. São Paulo: Nova Cultural, 1985. (Os Economistas).

MENEZES, Maia; LOUVEN, Mariza. Taxa de analfabetismo no país ainda é comparável à da África do Sul. O Globo, Rio de Janeiro, 21 dez. 2006. Economia, p.35.

MUDANÇA imperialista e escolarização de massa. Intervenção Comunista, Ano III, n.25, set.2005, p.9-10.

NUNES, Clarice. Anísio Teixeira. In: FÁVERO, Maria de Lourdes de Albuquerque; BRITTO, Jader de Medeiros. (Orgs.). Dicionário de educadores no Brasil: da Colônia aos dias atuais. 2. ed. Rio de Janeiro: Ed. UFRJ, 2002. p.71-79.

Apresentação. In: TEIXEIRA, Anísio. Educação é um direito. 3.ed. Rio de Janeiro: Ed. UFRJ, 2004. p.7-19.

OLIVEIRA, Francisco de. 'Política hoje é assunto de empresas'. O Globo, Rio de Janeiro, 19 ago. 2006. Prosa \& Verso, p.2.

PAULANI, Leda Maria. O projeto neoliberal para a sociedade brasileira: sua dinâmica e seus impasses. In: LIMA, Júlio César França; NEVES, Lúcia Maria Wanderley. (Orgs.).

Fundamentos da educação escolar do Brasil contemporâneo. Rio de Janeiro: Editora Fiocruz, 2006. p.67-107.

PISA analisa conhecimento científico dos jovens no mundo. Portal aprendiz, [S.I], 03 jul. 
A democratização do ensino com Anísio Teixeira versus educação brasileira em t... Página 22 de 32

2006. Disponível em: <http://www.clippingeducacional.com.br>. Acesso em: 03 jul. 2006.

POCHMANN, Márcio. Economia brasileira hoje: seus principais problemas. In: LIMA, Júlio César França; NEVES, Lúcia Maria Wanderley. (Orgs.). Fundamentos da educação escolar do Brasil contemporâneo. Rio de Janeiro: Editora Fiocruz, 2006. p.109-31.

SINGER, Paul. Apresentação. In: MANDEL, Ernest. O capitalismo tardio. São Paulo: Nova Cultural, 1985. (Os Economistas), p.VII-XXXIII.

O capitalismo. São Paulo: Moderna, 1991.

TEIXEIRA, Anísio. Educação pública: administração e desenvolvimento. Rio de Janeiro, DF: Oficina Gráfica do Departamento de Educação, 1935.

Educação para a democracia. 2.ed. Rio de Janeiro: Ed. UFRJ, 1997.

Educação é um direito. 3.ed. Rio de Janeiro: Ed. UFRJ, 2004.

UNIVERSIDADES vão ao mercado financeiro para fugir da crise. Portal Terra -

Educação, [S.I.], 26 jul.2006. Disponível em: <http://www.clippingeducacional.com.br>. Acesso em: 26 jul. 2006.

WEBER, Demétrio. Cai número de alunos que concluem ensino básico. $\mathbf{O}$ Globo, Rio de Janeiro, 7 dez. 2006. O País, p.15.

IPEA critica ação do MEC e cobra investimento. O Globo, Rio de Janeiro, 4 jan. 2007. O País, p.10.

WOOD, Ellen Meiksins. Democracia contra capitalismo. São Paulo: Boitempo, 2003.

$\left.{ }^{*}{ }^{\star}\right]$ Em sua versão original este ensaio foi apresentado como requisito para avaliação junto à disciplina Teoria e Educação II, do Programa de Pós-Graduação em Educação da Faculdade de Educação da Universidade Federal Fluminense, no segundo semestre de 2006. Ademais, alguns de seus trechos foram transcritos e/ou adaptados de partes dos trabalhos apresentados às disciplinas Teoria e Educação I, no primeiro semestre de 2006 e Políticas Públicas da Educação, do Programa de Pós-Graduação da Faculdade de Educação da Universidade Federal do Rio de Janeiro, no segundo semestre de 2006. Aproveito ainda para agradecer às Professoras Cláudia Alves e Clarice Nunes e Professor Osmar Fávero, da disciplina Teoria e Educação /l e Professores Osmar Fávero e José Rodrigues, pelos comentários e sugestões.

${ }^{\left.{ }^{* *}\right]}$ Docente da Universidade Federal de Roraima e doutorando do Programa de PósGraduação em Educação da Universidade Federal Fluminense

[1] Sobre a expressão modo de regulação, consultar o item 2.

[2] As Tabelas 1 a 17 podem ser consultadas no item ANEXO.

[3] A título de ilustração, sugerimos consultar as Tabelas 16 e 17, a respeito da queda do PIB dos países industrializados para os anos de 1960-1990 e queda da produtividade do trabalho no setor de negócios, também para os anos de 1960-1990.

[4] Debêntures são títulos de dívida remunerados a juros, emitidos por empresas no 
A democratização do ensino com Anísio Teixeira versus educação brasileira em t... Página 23 de 32

mercado de capitais para captar dinheiro. Informação obtida no site: <http://www.monitorfinanceiro.com.br>. Acesso em: 07/08/2006.

[5] Superávit primário: recursos do orçamento destinados ao pagamento dos juros da dívida pública. Para mais detalhes consultar: $<$ http://www.ibase.br/pubibase/media/Superavit_Primario.pdf>. Acesso em: 17/09/2006.

[6] Segundo Arcary (2005, p.44), 20 mil pessoas físicas recebem aproximadamente $R \$ 500$ mil por mês com a rolagem dos juros da dívida interna brasileira, que em junho de 2007 é a bagatela de $R \$ 1,3$ trilhões.

[7] Por limitações de espaço e tempo, a exposição sobre o neoliberalismo e a reestruturação produtiva no Brasil restringiu-se ao essencial. Na elaboração deste tópico foram consultados FIORI, José Luis. O consenso de Washington. Disponível em: <http://www.pdt.org.br/internacional/washington.asp>. Acesso em: 30 jan. 2007 e BATISTA, Paulo Nogueira. O consenso de Washington. São Paulo: PEDEX, 1995. (Coleção Cadernos da Dívida Externa). Sobre os aspectos de natureza econômica, baseamo-nos fundamentalmente em PAULANI (2006) e POCHMANN (2006).

[8] Segundo José Luis Fiori (nota 9), o primeiro país no qual foi implantada a política neoliberal foi o Chile, em 1973, mas ainda em caráter experimental.

[9] Ainda que com modificações, esse tipo de expediente não é exclusivo nem foi empregado pela primeira vez no governo Lula da Silva - o PROER (Programa de Estímulo à Reestruturação e ao Fortalecimento do Sistema Financeiro Nacional) - foi a versão do governo FHC de socorro aos bancos privados, cuja transferência de dinheiro público no período de 1995 a 2000 foi da ordem de $R \$ 30$ bilhões, valor que atualizado para o ano de 2005 corresponderia a R \$ 44,23 bilhões. Fontes: <http://pt.wikipedia.org> e $<$ http://www.pdt.org.br>. Acesso em: 28 mai. 2007.

[10] Informação fornecida por Roberto Leher, em conferência intitulada Crise e democracia no Brasil e a reforma universitária, proferida em 29/09/2006, na Faculdade de Educação da Universidade Federal Fluminense, quando da realização do Seminário Crise e democracia no Brasil, promovido pela Seção Sindical da Associação dos Docentes da Universidade Federal Fluminense e Secretaria Regional RJ do Sindicato Nacional da Associação Nacional dos Docentes de Ensino Superior.

[11] De acordo com os dados do artigo o artigo MUDANÇA ... (2005), na primeira metade do século XX, na Europa, a expansão da escolarização se dá principalmente quanto ao ingresso dos jovens nas escolas do ensino fundamental e médio. Assim, temos: Itália: entre 1921 e 1936, os estudantes do ensino médio passaram de 367.000 (10\% da faixa demográfica correspondente), para 685.000 (22\%, idem). Em 1951, houve retração para $10 \%$, com aumento vertiginoso nos anos posteriores: $22 \%$ em $1961,45 \%$ em 1971 e 99\% após o ano 2000. França: entre 1914 e 1936, as matrículas no ensino fundamental e médio passaram de cerca de 300 mil para um milhão.

\section{ANEXO}

TABELA 1

Valores referentes ao aumento do no de matrículas em relação ao ano letivo anterior nas escolas elementares públicas, diurnas e noturnas do Distrito Federal 
A democratização do ensino com Anísio Teixeira versus educação brasileira em t... Página 24 de 32

\begin{tabular}{|c|c|c|c|}
\hline Ano & $\begin{array}{c}\text { Total do } \\
n^{\circ} \text { de matrículas }\end{array}$ & $\begin{array}{c}\text { Aumento no no de } \\
\text { matrículas sobre o ano } \\
\text { anterior - valores } \\
\text { absolutos }\end{array}$ & $\begin{array}{c}\text { Aumento no no de } \\
\text { matrículas sobre o ano } \\
\text { anterior - valores } \\
\text { percentuais }\end{array}$ \\
\hline 1926 & 69169 & - & - \\
\hline 1927 & 71572 & 2403 & 3,47 \\
\hline 1928 & 76959 & 5387 & 7,52 \\
\hline 1929 & 79536 & 2577 & 3,34 \\
\hline 1930 & 85022 & 5486 & 6,89 \\
\hline 1931 & 92254 & 7232 & 8,50 \\
\hline 1932 & 92706 & 452 & 0,48 \\
\hline 1933 & 99188 & 6482 & 6,99 \\
\hline 1934 & 113776 & 14588 & 14,70 \\
\hline
\end{tabular}

Fonte: Teixeira, 1935, p.121

TABELA 2

Valores referentes ao aumento do oㅡ de matrículas em relação aos anos de 1910 a 1919 nas escolas primárias diurnas e noturnas e jardim de infância do Distrito Federal

\begin{tabular}{|c|c|c|c|}
\hline Ano & № de Matrículas & $\begin{array}{c}\text { Aumento no } \mathrm{n} \text { de } \\
\text { matrículas sobre o ano } \\
\text { anterior - valores } \\
\text { absolutos }\end{array}$ & $\begin{array}{c}\text { Aumento no } \mathrm{n} \text { - de } \\
\text { matrículas sobre o ano } \\
\text { anterior - valores } \\
\text { percentuais }\end{array}$ \\
\hline 1910 & 43588 & - & - \\
\hline 1911 & 46996 & 3408 & 7,81 \\
\hline 1912 & 49220 & 2224 & 4,73 \\
\hline 1913 & 55650 & 6430 & 13,06 \\
\hline 1914 & 63928 & 8278 & 14,87 \\
\hline 1915 & 71849 & 7921 & 0,79 \\
\hline 1916 & 72423 & 574 & 9,85 \\
\hline 1917 & 79563 & 7140 & $(-) 3,70$ \\
\hline 1918 & 76615 & $-) 2948$ & 8,86 \\
\hline 1919 & 83407 & 6792 & - \\
\hline TOTAL & 643239 & - & 7,62 \\
\hline MÉDIA & - & 4424,33 & \\
\hline
\end{tabular}

Fonte: Adaptado de Teixeira (1935, p.123)

file://C:LDocuments and Settings\AdministradorlMeus documentos\Minhas Webs\NED... 11/9/2008 
A democratização do ensino com Anísio Teixeira versus educação brasileira em t... Página 25 de 32

TABELA 3

Valores referentes ao aumento do oㅡ de matrículas em relação aos anos de 1920 a 1929 nas escolas primárias diurnas e noturnas e jardim de infância do Distrito Federal

\begin{tabular}{|c|c|c|c|}
\hline Ano & № de Matrículas & $\begin{array}{c}\text { Aumento no no de } \\
\text { matrículas sobre o ano } \\
\text { anterior - valores } \\
\text { absolutos }\end{array}$ & $\begin{array}{c}\text { Aumento no } \mathrm{n} \text { de } \\
\text { matrículas sobre o ano } \\
\text { anterior - valores } \\
\text { percentuais }\end{array}$ \\
\hline 1920 & 77744 & - & - \\
\hline 1921 & 81696 & 3952 & 5,08 \\
\hline 1922 & 82062 & 366 & 0,44 \\
\hline 1923 & 80996 & $(-) 1066$ & $(-) 1,29$ \\
\hline 1924 & 73562 & $(-) 7434$ & $(-) 9,17$ \\
\hline 1925 & 71434 & $(-) 2128$ & $(-) 2,89$ \\
\hline 1926 & 69169 & $(-) 2265$ & 3,17 \\
\hline 1927 & 71572 & 2403 & 7,52 \\
\hline 1928 & 76959 & 5387 & 3,34 \\
\hline 1929 & 79536 & 2577 & - \\
\hline TOTAL & 764730 & - & 0,37 \\
\hline MÉDIA & - & 199,11 & \\
\hline
\end{tabular}

Fonte: Adaptado de Teixeira (1935, p.123)

TABELA 4

Valores referentes ao aumento do oㅡ de matrículas em relação aos anos de 1930 a 1934 nas escolas primárias diurnas e noturnas e jardim de infância do Distrito Federal

\begin{tabular}{|c|c|c|c|}
\hline Ano & № de Matrículas & $\begin{array}{c}\text { Aumento no } \mathrm{n} \text { - de } \\
\text { matrículas sobre o ano } \\
\text { anterior - valores } \\
\text { absolutos }\end{array}$ & $\begin{array}{c}\text { Aumento no } \mathrm{n}^{\circ} \text { de } \\
\text { matrículas sobre o ano } \\
\text { anterior - valores } \\
\text { percentuais }\end{array}$ \\
\hline 1930 & 85022 & - & - \\
\hline 1931 & 92254 & 7232 & 8,50 \\
\hline 1932 & 92706 & 452 & 0,48 \\
\hline 1933 & 99188 & 6482 & 6,99 \\
\hline 1934 & 113776 & 14588 & 14,70 \\
\hline TOTAL & 482946 & - & - \\
\hline MÉDIA & - & 7188,5 & 7,59 \\
\hline
\end{tabular}

Fonte: Adaptado de Teixeira (1935, p.123)

file://C:LDocuments and Settings\Administrador\Meus documentos\Minhas Webs\NED... 11/9/2008 
A democratização do ensino com Anísio Teixeira versus educação brasileira em t... Página 26 de 32

\section{TABELA 5}

Valores referentes ao atendimento da população em idade escolar no sistema escolar público elementar do Distrito Federal -7 anos

\begin{tabular}{|c|c|c|}
\hline Ano & $\begin{array}{c}\text { № de Matrículas entre a } \\
\text { população em idade escolar } \\
\text { (7 anos) - valores absolutos }\end{array}$ & $\begin{array}{c}\text { № de matrículas entre a } \\
\text { população em idade escolar } \\
\text { (7 anos) - valores percentuais }\end{array}$ \\
\hline 1931 & 14262 & 60,41 \\
\hline 1932 & 13577 & 59,53 \\
\hline 1933 & 16550 & 65,18 \\
\hline 1934 & 21855 & 87,20 \\
\hline
\end{tabular}

TABELA 6

Valores referentes ao atendimento da população em idade escolar no sistema escolar público elementar do Distrito Federal -8 anos

\begin{tabular}{|c|c|c|}
\hline Ano & $\begin{array}{c}\text { № de Matrículas entre a } \\
\text { população em idade escolar } \\
\text { (8 anos) - valores absolutos }\end{array}$ & $\begin{array}{c}\text { № de matrículas entre a } \\
\text { população em idade escolar } \\
(8 \text { anos) - valores percentuais }\end{array}$ \\
\hline 1931 & 13620 & 62,60 \\
\hline 1932 & 14316 & 61,52 \\
\hline 1933 & 14604 & 64,75 \\
\hline 1934 & 15975 & 63,18 \\
Adeptade: Teixeira \\
(1935, \\
p.128)
\end{tabular}

TABELA 7

Valores referentes ao atendimento da população em idade escolar no sistema escolar público elementar do Distrito Federal -9 anos

\begin{tabular}{|c|c|c|}
\hline Ano & $\begin{array}{c}\text { № de Matrículas entre a } \\
\text { população em idade escolar } \\
(9 \text { anos })-\text { valores absolutos }\end{array}$ & $\begin{array}{c}\text { № de matrículas entre a } \\
\text { população em idade escolar } \\
(9 \text { anos }) \text { - valores percentuais }\end{array}$ \\
\hline 1931 & 12821 & 53,25 \\
\hline 1932 & 13729 & 62,87 \\
\hline 1933 & 14802 & 63,41 \\
\hline 1934 & 16595 & 73,35 \\
\hline
\end{tabular}

file://C:LDocuments and Settings\AdministradorlMeus documentos\Minhas Webs\NED... 11/9/2008 
A democratização do ensino com Anísio Teixeira versus educação brasileira em t... Página 27 de 32

\section{TABELA 8}

Valores referentes ao atendimento da população em idade escolar no sistema escolar público elementar do Distrito Federal - 10 anos

\begin{tabular}{|c|c|c|}
\hline Ano & $\begin{array}{c}\text { № de Matrículas entre a } \\
\text { população em idade escolar } \\
(10 \text { anos }) \text { - valores absolutos }\end{array}$ & $\begin{array}{c}\text { № de matrículas entre a } \\
\text { população em idade escolar } \\
(10 \text { anos }) \text {-valores } \\
\text { percentuais }\end{array}$ \\
\hline 1931 & 13284 & - \\
\hline 1932 & 13770 & 59,09 \\
\hline 1933 & 14593 & 66,71 \\
\hline 1934 & 16483 & 70,50 \\
\hline
\end{tabular}

Fonte: Adaptado de Teixeira (1935, p.128)

TABELA 9

Valores referentes ao atendimento da população em idade escolar no sistema escolar público elementar do Distrito Federal - 11 anos

\begin{tabular}{|c|c|c|}
\hline Ano & $\begin{array}{c}\text { № de Matrículas entre a } \\
\text { população em idade escolar } \\
\text { (11 anos) - valores absolutos }\end{array}$ & $\begin{array}{c}\text { № de matrículas entre a } \\
\text { população em idade escolar } \\
\text { (11 anos) - valores } \\
\text { percentuais }\end{array}$ \\
\hline 1931 & 12307 & - \\
\hline 1932 & 12776 & - \\
\hline 1933 & 12958 & 53,68 \\
\hline 1934 & 14745 & 67,34 \\
\hline
\end{tabular}

Fonte: Adaptado de Teixeira (1935, p.128)

TABELA 10

Valores referentes ao atendimento da população em idade escolar no sistema escolar público elementar do Distrito Federal - 12 anos

\begin{tabular}{|c|c|c|}
\hline Ano & $\begin{array}{c}\text { № de Matrículas entre a } \\
\text { população em idade escolar } \\
(12 \text { anos }) \text { - valores absolutos }\end{array}$ & $\begin{array}{c}\text { № de matrículas entre a } \\
\text { população em idade escolar } \\
\text { (12 anos) - valores } \\
\text { percentuais }\end{array}$ \\
\hline 1931 & 10797 & - \\
\hline 1932 & 10652 & - \\
\hline 1933 & 11522 & - \\
\hline
\end{tabular}

file://C:|Documents and Settings\AdministradorlMeus documentos\Minhas Webs\NED... 11/9/2008 
A democratização do ensino com Anísio Teixeira versus educação brasileira em t... Página 28 de 32

\begin{tabular}{|l|l|l|}
1934 & 11980 & 49,61 \\
\hline
\end{tabular}

Fonte: Adaptado de Teixeira (1935, p.129)

file://C:WDocuments and Settings\Administrador\Meus documentos\Minhas Webs\NED... 11/9/2008 
A democratização do ensino com Anísio Teixeira versus educação brasileira em t... Página 29 de 32

TABELA 11

Valores referentes à distribuição dos alunos pelas séries do curso elementar do Distrito Federal - 1930

\begin{tabular}{|c|c|c|}
\hline Séries & № de Matrículas & $\begin{array}{c}\text { Percentagem - } \mathrm{n}^{\circ} \text { de } \\
\text { matrículas no curso } \\
\text { elementar }\end{array}$ \\
\hline $1^{\mathrm{a}}$ & 39347 & 50,39 \\
\hline $2^{\mathrm{a}}$ & 17193 & 22,01 \\
\hline $3^{\mathrm{a}}$ & 11444 & 14,65 \\
\hline $4^{\mathrm{a}}$ & 6533 & 8,36 \\
\hline $5^{\mathrm{a}}$ & 3587 & 4,59 \\
\hline TOTAL & 78104 & 100 \\
\hline
\end{tabular}

Fonte: Teixeira (1935, p.130)

TABELA 12

Valores referentes à distribuição dos alunos pelas séries do curso elementar do Distrito Federal - 1931

\begin{tabular}{|c|c|c|}
\hline Séries & № de Matrículas & $\begin{array}{c}\text { Percentagem - } n^{\circ} \text { de } \\
\text { matrículas no curso } \\
\text { elementar }\end{array}$ \\
\hline $1^{\text {a }}$ & 42292 & 50,46 \\
\hline $2^{\underline{a}}$ & 18012 & 21,35 \\
\hline $3^{\text {a }}$ & 12716 & 15,14 \\
\hline $4^{\underline{a}}$ & 7142 & 8,50 \\
\hline $5^{\text {a }}$ & 3824 & 4,55 \\
\hline TOTAL $^{2}$ & 83986 & 100 \\
\hline
\end{tabular}

Fonte: Teixeira (1935, p.130)

file://C:|Documents and Settings\AdministradorlMeus documentos\Minhas Webs\NED... 11/9/2008 
A democratização do ensino com Anísio Teixeira versus educação brasileira em t... Página 30 de 32

TABELA 13

Valores referentes à distribuição dos alunos pelas séries do curso elementar

do Distrito Federal - 1932

\begin{tabular}{|c|c|c|}
\hline Séries & № de Matrículas & $\begin{array}{c}\text { Percentagem - no de } \\
\text { matrículas no curso } \\
\text { elementar }\end{array}$ \\
\hline $1^{\underline{a}}$ & 39773 & 38,35 \\
\hline $2^{\underline{a}}$ & 27424 & 26,42 \\
\hline $3^{\text {a }}$ & 19223 & 18,52 \\
\hline $4^{\text {a }}$ & 10840 & 10,44 \\
\hline $5^{\text {a }}$ & 6514 & 6,27 \\
\hline TOTAL $^{2}$ & 103774 & 100 \\
\hline
\end{tabular}

Fonte: Teixeira (1935, p.131)

TABELA 14

Número de Matrículas

Geral - Distrito Federal

\begin{tabular}{|c|c|c|c|c|c|}
\hline Ano & TOTAL & Federal & Estadual & Municipal & Particular \\
\hline 1932 & 232819 & 21657 & - & 135567 & 75595 \\
\hline 1933 & 225503 & 22436 & - & 126660 & 76407 \\
\hline 1934 & 277804 & 23615 & - & 147266 & 106923 \\
\hline 1935 & 279887 & 18873 & - & 148483 & 112531 \\
\hline
\end{tabular}

Fonte: Adaptado de Brasil, 1937, v.3 e Brasil, 1938, v.4

TABELA 15

Número de Matrículas

Geral - Brasil

\begin{tabular}{|c|c|c|c|c|c|}
\hline Ano & TOTAL & Federal & Estadual & Municipal & Particular \\
\hline 1932 & 2274213 & 35031 & - & 363515 & 499632 \\
\hline 1933 & 2466092 & 37617 & - & 370511 & 561247 \\
\hline 1934 & 2676756 & 39217 & - & 487304 & 598953 \\
\hline 1935 & 2862616 & 32527 & - & 567079 & 646559 \\
\hline
\end{tabular}

Fonte: Brasil, 1938, v.4

file://C:LDocuments and Settings\Administrador\Meus documentos\Minhas Webs\NED... 11/9/2008 
file://C:\Documents and Settings\Administrador\Meus documentos\Minhas Webs\NED... 11/9/2008 
A democratização do ensino com Anísio Teixeira versus educação brasileira em t... Página 32 de 32

TABELA 16

Produto Interno Bruto 1960-1992

Taxa de crescimento - média anual (\%)

\begin{tabular}{|c|c|c|}
\hline Período & Mundo & Países industrializados \\
\hline $1960 / 64$ & 4,94 & 4,94 \\
\hline $1965 / 69$ & 4,96 & 4,88 \\
\hline $1970 / 74$ & 4,14 & 3,62 \\
\hline $1975 / 79$ & 3,80 & 3,12 \\
\hline $1980 / 84$ & 2,40 & 1,86 \\
\hline $1985 / 89$ & 3,82 & 3,36 \\
\hline $1990 / 92$ & 2,53 & 1,50 \\
\hline
\end{tabular}

Fonte: Gorender (1995, p.107)

TABELA 17

Produtividade do Trabalho no Setor de Negócios (a)

Taxa de Variação Anual (\%)

\begin{tabular}{|c|c|c|c|}
\hline País\Período & $1960-73(\mathrm{~b})$ & $1974-79$ & $1980-91(\mathrm{c})$ \\
\hline EUA & 2,2 & 0,5 & 1,0 \\
\hline Japão & 8,3 & 3,6 & 2,9 \\
\hline Alemanha (d) & 4,5 & 3,4 & 1,8 \\
\hline França & 5,4 & 3,1 & 2,4 \\
\hline Itália & 6,3 & 2,7 & 1,8 \\
\hline Reino Unido & 3,6 & 2,3 & 2,2 \\
\hline Canadá & 2,8 & 1,7 & 1,4 \\
\hline
\end{tabular}

Obs: (a) Produto por pessoa empregada; (b) Reino Unido: 1961/73; França 1963/73; Canadá 1966/73; (c) Estados Unidos, Alemanha, França, Reino Unido: 1980/1992; (d) Alemanha Ocidental

Fonte: Gorender (1995, p.108)

\section{voltar}

file://C:LDocuments and Settings\Administrador\Meus documentos\Minhas Webs\NED... 11/9/2008 